\title{
Spatial evaluation of the apple trees-soil environment
}

\author{
Tamás, J. \\ Department of Water and Environmental Management, Centre of Agricultural Science, University of Debrecen, \\ Hungary, H-4032 Debrecen, Böszörményi street 138
}

\begin{abstract}
Summary: Remote sensing of fruit tree micro environment plays a major role in both horticultural and soil mapping applications. In frame this study presented a novel method to survey the spatial distribution of physical and water management properties of soils. The examinations were carried out at an intensive experimental apple orchard in Debrecen-Pallag. The examination site is the part of the Experimental Pomology plantation of the University of Debrecen, Faculty of Agronomy. Particle-size distribution, plasticity according to Arany, metal content by XRF spectrometry, soil physical parameters, acidity, electric conductivity of soils, were measured to obtain appropriate information on the physical properties of the soil. Based on the results, the accurate spatial positions of those sites were characterized where soil loosening should be implemented in 0,3-0,4 $\mathrm{m}$ depth. Spatially precise soil physical barriers were determined for applied micro-irrigation system. Based on the micro-element content and $\mathrm{pH}$, the accurate spatial positions of those sites were selected where melioration and micronutrient fertilization is needed. These detailed data sources also applied to calibrate the applied airborne hyperspectral images to extend spatially these point based information.
\end{abstract}

Key word: apple tree, micro environment, soil analysis, remote sensing, hyperspectral image spectroscopy

\section{Introduction}

It can be forecast with high probability that in future water will be the determining (hopefully not limiting) factor of food security and environmental safety in the Carpathian Basin (Somlyódy, 2000; Várallyay, 2002). Consequently, the role of real time detailed information in water use efficiency will be one of the key issues of fruit production.

The limited water resources and the increasing frequency of extreme hydrological events (floods, water-logging, overmoistening and drought) due to the high territorial and temporal variability of atmospheric precipitation; the heterogeneous (micro) relief; and the unfavorable physical/hydro physical characteristics of soils are pressing to improve agricultural water use efficiency and necessitates an efficient control of soil moisture regime in the Carpathian Basin (Pálfai, 2000; Várallyay, 1989).

Spatial variability of soil properties may appear in yield variation within a single field even in areas considered to be homogeneous from soil survey point of view. Effects of various sources of soil heterogeneity on the annual or longterm average soil water budget appear to differ markedly (Kim, 1995). Simulation models are tools for analyzing the moisture regime with respect to physical properties of soils (Majercak \& Novak, 1994; Djurhuus et al., 1999). The disadvantage of this approach is that it does not reflect the spatial pattern of the soil water balance elements. When used this tool in field scale models, have to be up-scaled from point validity soil profiles using geostatical methods (Van
Meirvenne et al., 1995; Tóth \& Kuti, 2002), or effective hydraulic parameters (Smith \& Diekkrüger, 1996). The use of effective hydraulic parameter values reduces the number of simulations significantly, but interprets the whole field as a homogeneous equivalent soil profile.

Traditional soil mapping is very time and cost consuming process. Remote sensing is the effective method to evaluate spatial pattern of the orchards within relatively short period. Sabins's, (1997) definition was about the remote sensing: the science of acquiring, processing, and interpreting images and related data, acquired from aircraft and satellites, that record the interaction between matter and electromagnetic energy. Remote sensing technologies make a possibility to the time series analyzing of the soils at an orchard and obtaining information of qualitative and quantitative water management parameters of soils (Berke et al., 2004).

The imaging spectroscopy technique, which provides near-laboratory-quality reflectance information, also has the capability to obtain non visible information and thus to produce a spatial overview of the mapping processes in large scales (Ben-Dor, 2002).

The analyzing technology, which was developed to survey the broadband spectral data, is incapable to exhaust all advantages of the hyperspectral remote sensing (Tamás \& Nagy, 2009). A major problem with traditional broad-band multispectral sensors - like SPOT, Landsat MSS, and Landsat ETM+- is the insufficient spectral resolution to map detailed soil features which exhibit subtle differences in spectral signatures (Clark, 1999). 
The presented hyper- and multispectral technology is used in the precision agriculture (Burai, 2006; Németh et al., 2007) but less experimental applications have known in fruit production and even less in real farm practice.

\section{Materials and methods}

The aim of this study was to present a complex process to evaluate the spatial distribution of physical and water management properties of soils. Based on results can be redesign field management especially the effect of high precipitation intensity on orchards. The examinations were carried out at an intensive

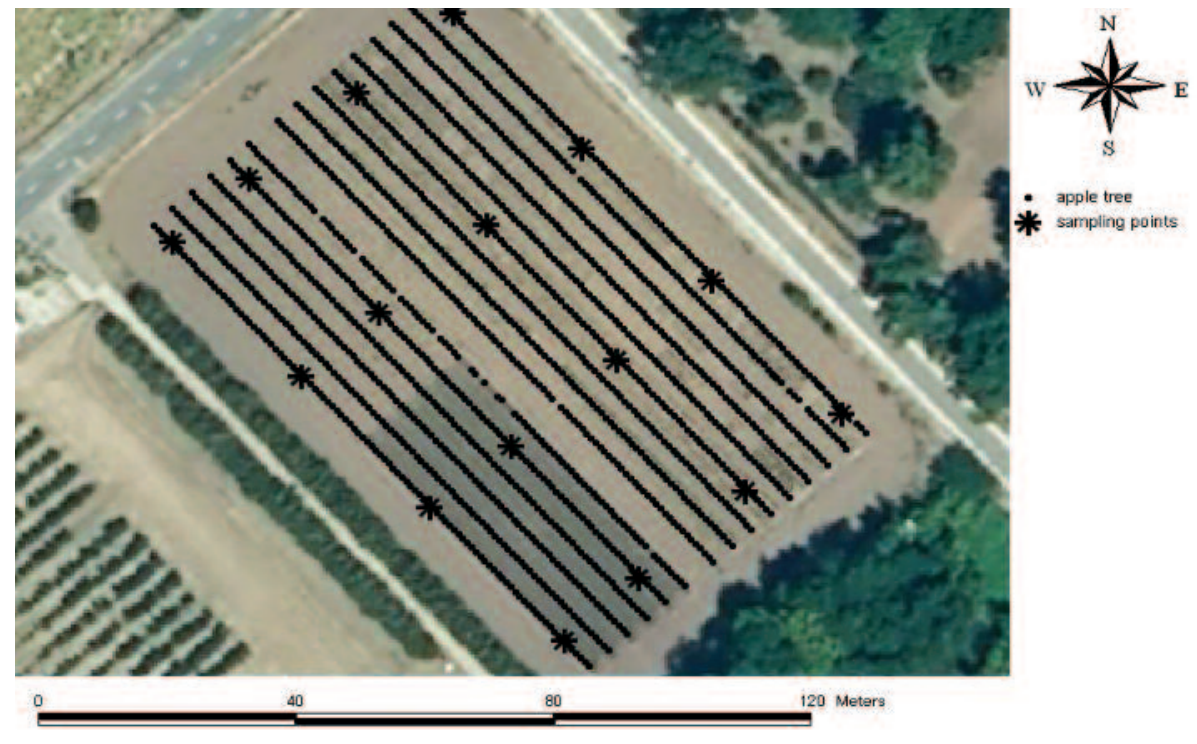
apple orchard in Debrecen-Pallag.

Figure 1: Research field and the sampling points

The examination Pomology plantation is the part of the Horticultural Experimental Farm of the University of Debrecen, Institute of Horticulture (Nyéki et al., 2005). Particle-size distribution, upper limit of soil plasticity according to Arany, element content by XRF spectrometry, maximum and field water capacity, soil density, acidity, electric conductivity of soils were measured to obtain appropriate information on the physical properties of the soil.

Due to the heterogeneous terrain surface special attention has to be paid to places with different location in order to examine all of the different soil varieties. The coordinates of the sampling points were collected by DGPS (Figure 1). Systematic grid sampling strategy was carried out based on the number of the rows and apple trees. The soil samples were collected by Eijkelkamp soil auger gauge from the surface and $0,4 \mathrm{~m}, 0,7 \mathrm{~m}$ depth. Undistributed soil samples were collected from $0.3 \mathrm{~m}$ depth to measure the water retention capacity.

The actual water content of the soil samples were determined by gravimetric method (W/V\%). The particle size fraction were measured by sieving, though $2 \mathrm{~mm}, 1 \mathrm{~mm}$, $630 \mu \mathrm{m}, 500 \mu \mathrm{m}, 315 \mu \mathrm{m}, 200 \mu \mathrm{m}$, and $100 \mu \mathrm{m}$ sieves. Based on the results the rate of particle size fractions were calculated in the $\mathrm{W} \%$ of the sample weight. The soil plasticity $\left(\mathrm{K}_{\mathrm{A}}\right)$, was also measured. Using the undistributed samples, water retention capacities were calculated at $\mathrm{pF}=0$ and $\mathrm{pF}=2.2$.

The soil permeability and water absorbing capacity were also measured with using infiltration boxes in field condition.

Soil compaction status was also measured on field by $3 \mathrm{~T}$ System penetrometer. The data of soil penetration resistance and the soil moisture at each centimeters was measured $(\mathrm{kPa})$ in root zone $($ depth $=0.60 \mathrm{~m})$. The actual soil moisture content was expressed in $\mathrm{V} \%$ of the field capacity ( $\mathrm{pF} 2.5$ ). The $\mathrm{pH}$ and electric conductivity of the soil samples were measured by EBRO and WTW LF 320/SE devices, in 1:2.5 ratio of water - soil suspension. The elements (Fe, $\mathrm{K}$ and $\mathrm{Ca}$ ) content of the air dried and sieved $(<2 \mathrm{~mm})$ soil samples were determined by NITON $\mathrm{XL}_{\mathrm{t}} 700$ field portable XRF spectrometer. The spatial heterogeneities of the experimental site were calculated by Surfer 9.0 and spectral evaluation was carried out by ENVI 4.6 software.

In August 2009, the spectral and spatial data with high ground $(1 \mathrm{~m})$ resolution was collected by AISA DUAL airborne hyperspectral camera. The instrument operated in cooperation the University of Debrecen, AMTC, Department of Water and Environmental Management with the Mechanization Institute of Agricultural Ministry in Gödöllő. The most important parts of the hyperspectral sensors are the spectrograph, which dissolve the electric waves arrived through the optical rift with the help of prisms and optical screen. The two hyperspectral sensors are used in common house; therefore it is known ASIA DUAL system. The two cams can perceive in the visible wavelength, near infrared range and short wave infrared range. Wavelength: 400-2450 nm (EAGLE: 400-970 nm and HAWK: 970-2450 nm) which is suitable for the determination of minerals and quartz detection (Kardeván, 2003).

\section{Results and discussion}

Based on soil plasticity (AK), different characteristics could be distinguished in every layer: surface, $0,4 \mathrm{~cm}$ and 0,7 m (Figure 2).

Since the maximal value $\left(\mathrm{K}_{\mathrm{A}}=30\right)$ measured at the sampling point with the lowest altitude, it was caused by the relief. Significant differences among these parameters of the three soil layers cannot be found.

Based on size distribution of the soil materials, the rate of the coarse sand fractions were high and significant differences among sand fractions of the three soil layers also not be found (Table 2). 


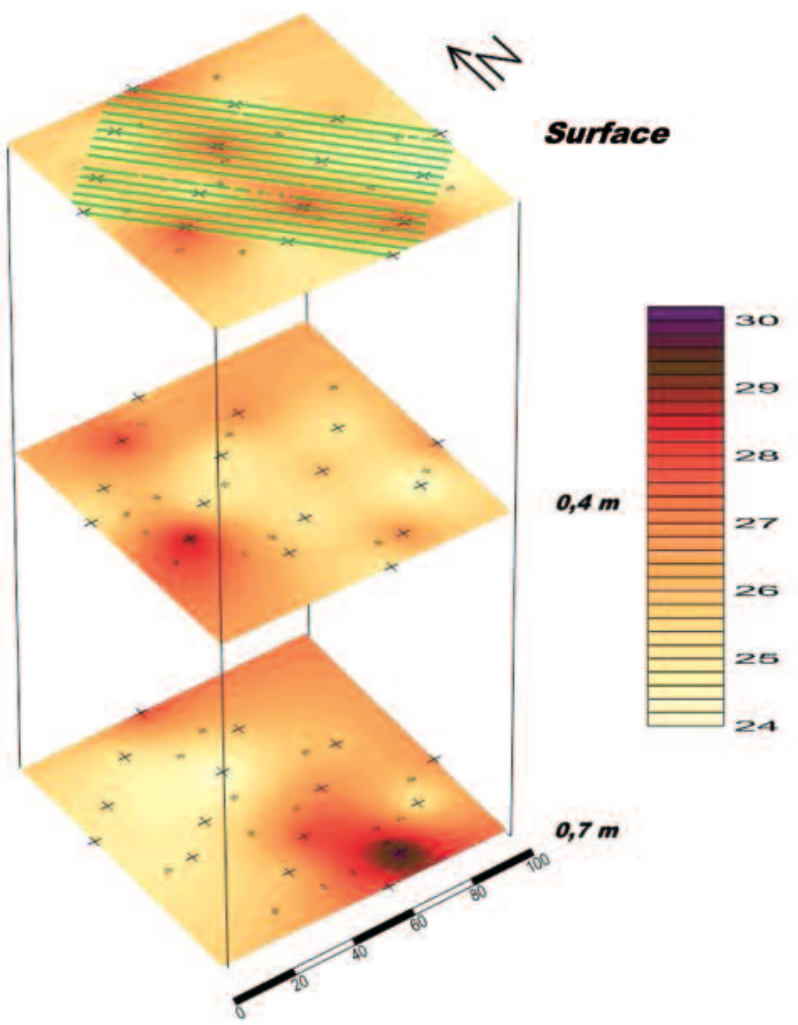

Figure 2: Spatial distribution of soil plasticity (apple trees illustrated as points on the surface layer)

Table 2. Statistics of the coarse sand fractions (\%)

\begin{tabular}{|c|c|c|}
\hline Depth & Mean & St. Dev. \\
\hline Surface & 76,91 & 2,45 \\
\hline $\mathbf{4 0} \mathbf{~ c m}$ & 77,65 & 2,90 \\
\hline $\mathbf{7 0} \mathbf{~ c m}$ & 77,52 & 3,82 \\
\hline
\end{tabular}

The spatial variability of the actual volumetric water content were lows in all layers, in root zone of the dripirrigated apple orchard (Table 3).

Table 3. Actual water content (V\%) in the three soil layers

\begin{tabular}{|c|c|c|}
\hline Depth & Mean & St. Dev. \\
\hline Surface & 9,44 & 1,83 \\
\hline $\mathbf{4 0} \mathbf{~ c m}$ & 12,83 & 267 \\
\hline $\mathbf{7 0} \mathbf{~ c m}$ & 12.85 & 2,13 \\
\hline
\end{tabular}

However, the spatial distribution of maximal $\left(\mathrm{WH}_{\max }\right)$ and minimal $\left(W H_{\text {min }}\right)$ water retention capacities were heterogeneous. Based on the results, 180-260 mm/m minimal water retention capacity was measured, which is typical for sandy loam soils (Table 4). This more heavy textured statement is contradicted to the results of the saturation light sandy soil.

This contradiction is fairly caused by the increased soil density of the compacted layer.
Table 4. Maximal $\left(\mathrm{WH}_{\max }\right)$ and minimal $\left(\mathrm{WH}_{\min }\right)$ water retention capacities of the soil samples

\begin{tabular}{|c|c|c|}
\hline & Mean & St. Dev. \\
\hline $\mathbf{V H}_{\max }$ & 42,5 & 2,56 \\
\hline $\mathbf{V H}_{\min }$ & 24,23 & 4,74 \\
\hline
\end{tabular}

Even in the 0,2-0,3 $\mathrm{m}$ soil layer the soil density reached and exceeded the $3 \mathrm{MPa}$ soil penetration resistance value, which is typical for the heavily compacted soil condition (Birkás, 2002). The mean penetration resistance values of deeper soil layers were clearly exceeded this threshold. These properties of the soil profile basically influenced more soil water related process.

At the Eastern part of the examined apple orchard site, sandstone layer with extreme high soil density was found at $0,3-0,4 \mathrm{~cm}$ depth. At this layer penetration resistance values exceeded the upper limit of the measurement range (10 000 $\mathrm{kPa}$ ) of the penetrometer, therefore it was not possible to measure deeper soil layers

Hyperspectral spectral curve were collected at sampling points of sample area to analyze spectral curves (Figure 3). The spectral profile shows the spectral value regarding to 1 pixel $\left(0,25 \mathrm{~m}^{2}\right)$ in case of all channels.

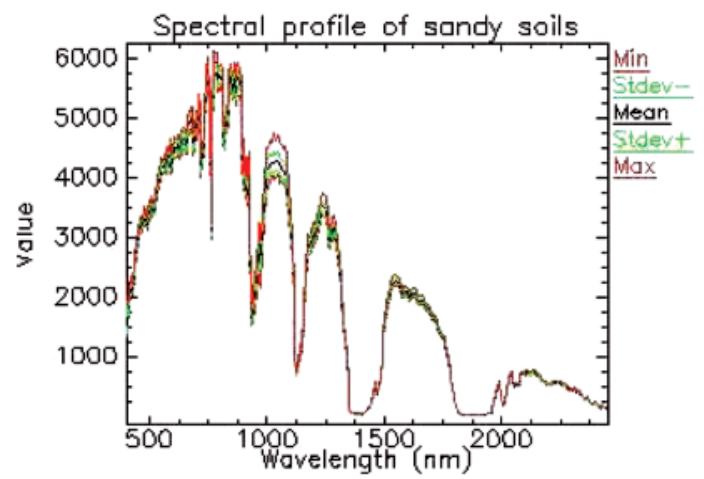

Figure 3. The spectral curves and the statistics of the spectral profile of the barren surface

Correlation analysis was investigated between the reflectance values of the channels, and the field measurement results. Significant correlations (significance level<0.05) were found between the minimal water retention capacity and the following range of channels (400-1345 nm, $(\mathrm{R}=0.7)$; 1640-1797 nm, $(\mathrm{R}=0.5) ; 2331-2413 \mathrm{~nm}, \quad(\mathrm{R}=0.5))$. Correlation factors are mean values.

\section{Acknowledgement}

The author thanks László Fenyvesi, József Nyéki, Zoltán Szabó, Csaba Lénárt, Péter Burai, Attila Nagy and Tünde Fórián for insuring of the data base and the professional advices. This research work was funded by NKTH GYUM2008; BIODEB08; KLIMA09 GVOP 3.1.1-2004-050087/3, FVM31174/1/2008 projects. 


\section{References}

Ben-Dor, E., (2002): Quantitative remote sensing of soil properties. Advances in Agronomy 75. 173-243.

Berke, J., Kelemen, D. \& Szabó, J., (2004): Digitális képfeldolgozás és alkalmazásai. PICTRON Kft., Keszthely

Burai P. (2006): Földhasználat-elemzés és növény-monitoring különböző adattartalmú és térbeli felbontású távérzékelt felvételek alapján. Agrártudományi Közlemények, 22. 7-12.

Clark, (1999): Spectroscopy of rocks and minerals, and principles of spectroscopy. (In: A. Rencz, Editor, Remote sensing for the earth sciences: Manual of remote sensing) Vol. 3, John Wiley and Sons, New York, 3-58.

Djurhuus J. (1999): Modelling mean nitrate leaching from spatially variable fields using effective hydraulic parameters. Geoderma, 87. 261-279.

Kardeván, P., Vekerdy, Z., Róth, L., Sommer, ST., Kemper, TH., Jordan, GY., Tamás, J., Pechmann, I., Kovács, E., Hargitai, H. \& László F. (2003): Outline of scientific aims and data processing status of the first Hungarian hyperspectral data acquisition flight campaign, HYSENS 2002, HUNGARY. 3rd EARSEL Workshop on imaging spectroscopy, 324-332.

Kim R. (1995): The water budget of heterogeneous areas. Doctoral thesis. Wageningen Agricultural University. Wageningen, The Netherlands

Majercak, J. \& Novák, V. (1994): One dimensional variably saturated flow model. GLOBAL. Version 2.1. Institute of Hydrology, Slovak Academy of Sciences. Bratislava, Slovak Republic.

Németh, T., Neményi, M. \& Harnos, Zs. (2007): Methodology of Precision Agriculture (in Hungarian) JATE Press., 1-238.

Nyéki, J., Szabó, Z., Nagy, J., Soltész, M., Fári, M., Holb, I., Lakatos, L., Racskó, J., Drén, G., Thurzó, S., Dani, M., Budai,
L., Erdős, Z., Popovics \& L. Szabó, T. (2005): Research fields of the institute for Extension and Development of the University of Debrecen Centre of Agricultural Sciences. (In: Jávor, A., Kátai, J. \& Tamás, J. (eds.): Sustainable Agriculture Across Borders in Europe), University of Debrecen Press, Debrecen-Oradea, 225-228.

Pálfai I. (Ed.) (2000): The role and significant of water in the Hungarian Plain. (In Hungarian) Nagyalföldi Alapítvány. Békéscsaba

Sabins, F., F., (1997): Remote Sensing - Principles and Interpretation, 3rd edn., W.H. Freeman, New York, NY. 1-494.

Smith, R., E. \& Diekkrüger, B. (1996): Effective soil water characteristics and ensemble soil water profiles in heterogeneous soils. Geophys. Res, 32. 1993-2002.

Somlyódy L. (2000): Strategy of Hungarian water management (In Hungarian). MTA Vízgazdálkodási Tudományos Kutatócsoportja, Budapest, pp.1-370.

Tamás, J. \& Nagy, I., (2009): Őszibarack ültetvény lombozatának vizsgálata hiperspektrális adatok alapján. AGRO 21

Tóth, T. \& Kuti, L., (2002): Testing alternative techniques of numerical simulation versus repeated field instrumental measurements for assessing soil salinity status in a sodic grassland. Agrokémia és Talajtan, 51. 243-252.

Van Meirvenne, M. (1995): Spatial extension of a point water balance model. In: Scenario Studies for the Rural Environment. (Eds.: Schoute, J. F. TH. et al.) 293-297. Kluwer. The Netherlands.

Várallyay, Gy. (1988): Soil, as a factor of drought-sensitivity of biomass production (In Hungarian). Vízügyi Közlemények, LXXX. (3) 46-68.

Várallyay, Gy. (2002): The role of soil and soil management in drought mitigation . In: Proc. Int. Conf. On Drought Mitigation and Prevention of Land Desertification, Bled, Slovenia, April 21-25 2002. ICID-CIIC. (CD) 